\title{
Real Convergence In The European Union: “New" Versus “Old” Member States
}

\author{
https://doi.org/10.21272/sec.4(4).5-17.2020
}

Ana-Maria Holobiuc, ORCID: https://orcid.org/0000-0001-9329-9758

$\mathrm{PhD}$ Candidate, Doctoral School of Economics and International Affairs, The Bucharest University of Economic Studies, Romania

\begin{abstract}
The recent waves of enlargement of the European Union have created not only opportunities, but also challenges, emphasizing the complexity of the integration process and the difficulty to assure cohesion between Members. The aim of this paper is to examine real convergence in an enlarged European Union and to conduct a comparative analysis between the New (13) and the Old Members (15). In this respect, we have studied absolute and conditional convergence between 1995 and 2019, taking into consideration the level of GDP per capita. The methodological tools of the research were $\beta$-convergence based on cross-sectional and panel regressions and $\sigma$ convergence. The results of our study confirm the $2 \%$ law of convergence within the European Union between 1995 and 2019. However, the analysis of the economic performances among the New and Old Members led us to opposite results: while the catching-up speed among the New Member States reached on average $2.7 \%$, in the Old Members we didn't identify a statistically significant relationship between the initial income and the subsequent growth rates. In order to account for economic and social differences between the Member States, we have examined conditional convergence, illustrating the defining role of investment, trade and labor productivity in catalyzing convergence both in the New and Old Members. In contrast, the empirical study suggests that an increased level of public expenditures and over-indebtedness within the European Union threaten the catching-up process. The results of our paper can be useful for the European decision makers, illustrating the factors that might contribute to the achievement of the objective of real convergence within the European Union.
\end{abstract}

Keywords: real convergence, European Union, New Member States, $\beta$-convergence, $\sigma$-convergence.

JEL Classification: O40, O52, O57.

(c) (i)

Cite as: Holobiuc, A.-M. (2020). Real Convergence In The European Union: "New" Versus "Old" Member

States. SocioEconomic Challenges, 4(4), 5-17. https://doi.org/10.21272/sec.4(4).5-17.2020.

(C) The Author, 2020. This article is published with open access at Sumy State University.

\section{Introduction}

The establishment of the European Coal and Steel Community and soon after of the European Economic Community represented an unprecedented initiative that shifted the historical course of the European continent, transforming war in peace, defragmentation into integration and former foes in friends. Being initially founded by six European countries in order to strengthen the economic ties between them and to avoid the political conflicts that affected for long time the regional prosperity and stability, the European Union encompasses nowadays twenty-seven countries, with the prospects to expend towards the East and South of the continent. The 
SocioEconomic Challenges, Volume 4, Issue 4, 2020

ISSN (print) - 2520-6621, ISSN (online) - 2520-6214

accession of the former communist countries brought to the fore the necessity to assure economic convergence between countries and regions given the lower performance of these countries and the structural vulnerabilities inherited from the communist regime. The main purpose of this paper is to study real convergence between 1995 and 2019, trying to respond to the question if income convergence is an achievable objective in an enlarged European Union. Moreover, we have tried to conduct a comparative analysis between two subgroups of countries - New and Old Member States - in order to respond to the question if the Central and Eastern European countries are catching-up or lagging behind. The former group encompasses the Central and European states, together with Cyprus and Malta, while the latter includes the countries that founded the European Union and joined the group in the last century. Our study is based on the assumption that the New Members have made significant progress in terms of income convergence as reflected by $\beta$ - and $\sigma$-indicators.

In order to test the assumptions of our research, we have studied absolute and conditional $\beta$-convergence based on cross-sectional and panel regressions and $\sigma$-convergence by taking into consideration the coefficient of variation of the data sets. The results of our study indicate an aggregate convergence speed of $1.9 \%$ per year under the absolute framework. The subgroup analysis led us to opposite results. Among the New Member States group, the average catching-up speed between 1995 and 2019 was $2.7 \%$. In contrast, we didn't identify statistically significant evidence in favor of the neoclassical assumptions among the Old Members cluster. Taking into consideration that the European economies differ in their initial conditions and may reach different states of equilibrium, we have also tried to study conditional convergence. In contrast with absolute convergence, the conditional model allows for controlling the structural differences between economies. In this respect, we have initially studied the influence of five economic variables (gross fixed capital formation, general government final consumption expenditure, general government debt, general government deficit and trade), then expanding the panel regression with factors aiming the demography and labor market (real labor productivity per person, population growth, labor force participation rate and unemployment). By applying panel regressions using generalized method of moments technique (GMM) (Arellano and Bond, 1991), we have illustrated that investment in fixed assets, the government deficit, the openness to trade and the improvement of the labor productivity had a positive influence on economic growth between 1995 and 2019 both at aggregate and subgroup level. However, our study suggests that an increase level of government spending and over-indebtedness hampered the convergence process between 1995 and 2019. As far as $\sigma$-convergence is concerned, the results of our study confirm a decrease of income gaps at aggregate level but opposite trends within the two subgroups.

Overall, we have tried to contribute to the economic growth literature by conducting a comparative analysis between the New and Old Members. In this respect, we have found evidence in favor of the $2 \%$ law of convergence, identifying a higher speed of catching-up within the poorer Central and Eastern European countries. The analysis of conditional convergence at aggregate and subgroup level provided us some insightful evidence regarding the economic and social determinants of catching-up process. In this respect, the empirical analysis suggests that the European decision makers should rethink the economic growth model, by focusing on investments, trade liberalization and increasing the productivity of labor. Moreover, our paper emphasizes the need to assure a sustainable convergence between Members, aiming low levels of public expenditures and debt. The recent economic and financial crisis illustrated the vulnerabilities of the economic growth model based on excessive public debt. Particularly, the most affected countries from Southern Europe still face difficulties in promoting economic growth. In the absence of the reconfiguration of the growth model, this group of economies will not succeed to keep pace with the other Members, especially the Central and Eastern European countries. These trends are worrying and might pose into question the objective of economic cohesion within the European Union. 
SocioEconomic Challenges, Volume 4, Issue 4, 2020

ISSN (print) - 2520-6621, ISSN (online) - 2520-6214

The paper is structured as follows. Section 2 illustrates the relevant theoretical and empirical studies referring to the convergence process in the European Union, while the Section 3 presents the data and methodology used in order to test the assumptions of our paper. In the Section 4, we have tried to explain the main results of the study, while in the last part we have summarized the findings and proposed future directions of research.

\section{Literature review}

Real convergence has become a debated topic with the establishment and advancement of the regional integration process within the European continent, evolving in close relationship with the economic growth theories. In contrast with the nominal convergence criteria, which are defined in the Maastricht Treaty, the real determinants are not strictly determined in the Community's official documents. The absence of a unitary view on its definition, scope or determinants does not make real convergence less important in the analysis of the economic performances of the European Union. By contrast, analysis have become increasingly interested on this topic, usually considering real convergence a complementary pillar of the nominal criteria. According to Matkowski and Próchniak (2007), real convergence aims the reduction of income gaps - income convergence - and the similarity of business cycles between economies - cyclical convergence.

The process of regional enlargement that started in 1973 and quickly advanced at the beginning of the 2000s has changed the European geo-political landscape. The accession of the Central and Eastern European countries has represented an unprecedented moment in the history of the European Union that has been largely discussed in the academic and governmental institutions. Particularly, researchers conducted in-depth analysis of the macroeconomic landscape of the European Union and comparisons between the "Old" and the "New Member States" (Rapacki and Próchniak, 2009; Vojinović et al., 2009; Stanišić, 2012; Dobrinsky, 2013; Dauderstädt, 2014; Matkowski et al., 2016; Diaz del Hoyo et al, 2017; Gros, 2018; Stoica et al, 2019, Rapacki and Próchniak, 2019). Moreover, there are also researchers that studied the evolution of the real determinants in connection with the synchronization of the business cycles (Matkowski and Próchniak, 2007) or the fulfillment of the nominal criteria (Kutan and Yigit, 2005; Forgó and Jevčák, 2015)

Vojinović et al. (2009) analyzed real convergence in the Central and Eastern European countries that joined the European Union in 2004, illustrating that during the initial transition period (first half of the '90s), the group experienced significant decline in output, rising unemployment and high inflation rates. Vojinović et al. outlined that real convergence started in the second half of the ' 90 s and continued at the beginning a third millennium, the catching-up speed reaching 4.2\% between 1992 and 2006 and 7.0\% - 9.6\% between 2002 and 2006. In the same line, Dobrinsky (2013) studied income convergence in the European Union between 1995 and 2011 (absolute convergence) and 2000 and 2011 (conditional convergence), concluding that the New Member States formed a convergence club. Similar to other analysts (Mankiw et al. 1992, Barro and Sala-i-Martin, 1992), Dobrinsky identified a uniform convergence speed of $2 \%$, both in the absolute and conditional framework. At the same time, the analyst illustrated that the convergence process in Central and Eastern Europe continued even after the outbreak of the financial crisis. In contrast, Stoica et al. (2019) identified a convergence speed of $2.6 \%$ between 1995 and 2018 under the absolute framework, concluding that the crisis negatively influenced the catching-up process, mainly in the New Members States.

Matkowski and Próchniak (2007) found evidence in favor of $\beta$-convergence for both Central and Eastern European subgroup (8) and the Old Members (15) between 1993 and 2004, concluding that the growth rates increased mainly between 1998 and 2004. In the European Union, the average GDP growth rate was approximate $2.4 \%$ per year, while in Central and Eastern Europe the percentage was slightly higher (2.5\%). Similarly, Stanišić (2012) identified a convergence speed around 1.7\% at aggregate level between 1993and 2010, but rejected the 
SocioEconomic Challenges, Volume 4, Issue 4, 2020

ISSN (print) - 2520-6621, ISSN (online) - 2520-6214

absolute convergence hypothesis for the subgroup analysis. Rapacki and Próchniak (2009) examined absolute convergence between 1996 and 2007 and concluded that the Central and Eastern European countries experienced a higher convergence speed compared to the Old Members (15), reaching on average $2.8 \%$ per year. In another study, Rapacki and Próchniak (2019) examined conditional convergence between 1995 and 2015 and identified a convergence speed of $2.2 \%$. The leaders of the catching-up process were the Baltic States, which recorded annual growth rates of 4.5-5\%. In the group of former members, Luxembourg and Ireland experienced the highest growth rates. Rapacki and Próchniak pointed out that the New Member States need 30-35 years to reduce reach the halfway of the transition period towards the equilibrium state. In the same line, Matkowski et al. (2016) studied conditional convergence, identifying a convergence speed reaching on average $3.2 \%$ per year for the Central and Eastern European group and 1.5\% for the Old Member States. In contrast, Gros (2018) identified higher growth rates between 1999 and 2016 in Central and Eastern Europe, reaching on average 6\% per year. In the Old Members group, the catching-up speed was around $2 \%$, and the income gaps between North and South increased.

Rapacki and Próchniak (2009) examined the factors that enhanced convergence, taking into consideration variables related to the European Union membership and other indicators aiming the economic and social framework. The researchers highlighted that the accession to the European Union enhanced income convergence in Central and Eastern Europe. At the same time, the process of economic growth was catalyzed by the improvement of institutional quality and trade and financial integration. Similarly, Próchniak (2011) studied the key drivers of convergence in the Central and Eastern Europe between 1993 and 2009, concluding that the determinants from the demand side mainly influence the short-term economic growth, while the factors on the supply side have a long-term effect. The analyst pointed out that FDI and gross fixed capital formation played a major role in enhancing economic growth in the Central and Eastern European region. At the same time, Próchniak highlighted the defining role of human capital, illustrating that a higher proportion of employees with tertiary education will positively influence the GDP growth rate. At the same time, the analyst highlighted the existence of a negative relationship between the deficit and public debt and economic growth, concluding at the same time that the structure of the economy did not influence the GDP dynamics. In terms of population structure, Próchniak pointed out that a higher share of the active population will lead to higher growth rates. Stoica et al. (2019) empirically demonstrated that investment played a major role in aggregate growth, while inflation, capital flows and private lending had a negative impact. The analysis of the subgroups showed that the convergence rate was higher for the Old Member States under the conditional framework, given the favorable influence of the macroeconomic and institutional variables. In the same line, Stanišić (2012) demonstrated that the convergence process was positively influenced by the level of education and life expectancy at birth, investment, exports and a high public balance. In contrast, the growth rate was inversely correlated with the fertility rate and inflation. Overall, the analyst concludes that despite the convergence rates identified, the recovery process is lengthy, so equalization of events is not likely in the near future.

Nenovsky and Tochkov (2013) considered that the implementation of the market oriented reforms in the Central and Eastern European economies, as well as the investments in human capital, played a key role in catalyzing convergence. In contrast, the different capital accumulation rates and the price instability have enhanced the income gaps between economies. Similarly, Diaz del Hoyo et al. (2017) noted that the transition to the market economy and the effort to integrate the acquis communautaire had a more important contribution in enhancing the economic performances in the New Member States, compared to the adoption of the single currency. This conclusion might be increasingly relevant nowadays, when two ex-communist countries, Bulgaria and Croatia, entered into the Exchange Rate Mechanism II. 
Apart from studying the absolute and/or the conditional convergence, analysis were also interested in identifying if the income differentials between economies diminish over time, as reflected by $\sigma$-convergence. In this respect, Matkowski and Próchniak (2007) concluded that income gaps between subgroups and at aggregate level diminished between 1993 and 2004, although the difference between New and Old Members were still high. Similar conclusion were reached by Rapacki and Próchniak (2009), who illustrated that the disparities decreased both within subgroups and in the European Union (25) between 1996 and 2007. Stanišić (2012) illustrated that income gaps decreased within EU (25) between 1993 and 2010, the process being interrupted by the economic and financial crisis, which negatively influenced convergence in 2009. In contrast, the analysis identified opposite trends between New and Old Members: while in the former group, the income convergence was negatively influenced by the crisis, in the latter, the divergences of the composing countries continued to decrease.

\section{Data and Methodology}

The empirically studies aiming the topic of economic growth have been developed in the $20^{\text {th }}$ century, initially by the neoclassical growth model exponents (Ramsey, 1928; Solow, 1956). The debate between the neoclassical and endogenous growth model exponents was accompanied by quantitative studies aiming to demonstrate the role of production factors and technological progress. In order to examine convergence in the European Union, we have employed $\beta$ - and $\sigma$-convergence, two instruments that were popularized by Barro and Sala-i-Martin (1992). The concept of $\beta$-convergence aims a potentially negative relationship between the initial level of income and the subsequent growth rates. In the economic growth literature, researchers have developed two frameworks for the study of $\beta$-convergence: absolute and conditional. Duro (2012) noted that the exponents of the neoclassical model of economic growth have popularized the concept of absolute convergence, which refers to the process in which less developed economies have higher growth rates than rich ones. In contrast, conditional convergence assumes that the growth rate will be determined by the particular conditions of each economy and the speed of convergence will depend on the distance of each economy from its own equilibrium. According to Barro and Sala-i-Martin (1992), $\beta$-convergence may be accompanied by $\sigma$-convergence if the income gaps between economies decrease over time.

We have initially studied absolute convergence based on cross-sectional regressions taking as dependent variable the average GDP per capita growth rate between 1995 and 2019 and as explanatory variable the initial level of income. In the second part of our paper, we have examined conditional convergence by expanding the equation and including economic and social variables in order to control the structural differences between economies. In this respect, we have constructed two models, which were estimated on panel regressions for the European Union and the two subgroups. We have initially selected five explanatory variables aiming the economic framework the level of investments, the soundness of the public finance and the trade openness. Then, the equation was expanded with variables aiming the demography and the labor market, which might explain the growth rate differentials between countries. The dependent variable was the difference of logarithms of the GDP per capita. Data included in our research was Available at: Eurostat and World Bank.

In order to study $\sigma$ - and (absolute) $\beta$-convergence, we have taken into consideration the (log) GDP per capita for all the Member States, as provided by Eurostat. The conditional $\beta$-convergence included, besides the $\log$ of GDP per capita, the following explanatory variables, defined in table 1 :

In order to test (absolute) $\beta$-convergence, we have employed a simple cross-sectional regression, where the independent variable is the log of initial GDP per capita (1995) and the dependent variable the average growth rate between 1995 and 2019: 
SocioEconomic Challenges, Volume 4, Issue 4, 2020

ISSN (print) - 2520-6621, ISSN (online) - 2520-6214

The speed of convergence was computed as follows:

The conditional convergence was studied based on panel regression. In this respect, we have initially included as explanatory variables the lagged value of the GDP per capita, the gross fixed capital formation (\% of GDP), the government final consumption expenditure ( $\%$ of GDP), the government debt and deficit ( $\%$ of GDP) and the volume of trade (\% of GDP):

As follows, we have expanded the equation 3, by adding other explanatory variables that are representative for the labor market (real labor productivity per person, labor force participation rate, unemployment) and demography (population growth rate)

With the purpose to study if the income gaps between the 28 Member States diminish over time, we have computed $\sigma$-convergence taking into consideration the coefficient of variation of the data sets:

Table 2 illustrates the statistical descriptions of the variables included in our study for European Union (28) and the two subgroups (New and Old Member States). As reflected by the average values of the variables under examination, there still persist significant divergences between the New and the Old Members. Moreover, the minimum and the maximum values suggest that the comprising countries do not have homogenous performances. Based on the values of GDP per capita, we expect to find different convergence speeds in the two subgroups. In the second part of our study, the other explanatory variables will complete the analysis of convergence patterns. In this respect, we expect that the gross fixed capital formation, the level of deficit, debt, trade, real labor productivity and labor force participation to positively influence the dependent variables. In contrast, factors such as government consumption, population growth and unemployment might have negative impact on convergence both at aggregate and subgroup level.

\section{Results}

Figure 1 illustrates the results of the absolute $\beta$-convergence, computed based on equation 1 . The negative slope of the trend line confirms the negative relationship between the initial GDP per capita and the subsequent growth rates. Consequently, the initially poorer Members experienced higher GDP growth rates between 1995 and 2019than the developed countries. Particularly, the Central and Eastern European countries, which are mainly grouped in the upper part of the figure, have been catching-up, experiencing average growth rates above Community's average. The highest growth rates were experienced by the three Baltic Countries exceeding $4 \%$ per year. In the European Union group (15), the highest GDP per capita growth rates were recorded by Ireland $(4 \%)$ and Austria (3.7\%), while the lowest by Italy $(0.3 \%)$. Our analysis suggests that the European countries tend to form two different clubs, based on income. The New countries from Central and Eastern Europe are clustered in the upper part of the figure, recording GDP growth rates above $2 \%$, while the majority of the Old Members, with the exception of Ireland and Austria have experienced modest economic performances, below 2\%, being grouped in the other extremity of the figure.

Table 3 presents the regression results of absolute $\beta$-convergence, applied for the European Union (28), the New Member States (13) and the Old Member States (15). As shown by the value R-squared, the initial level of income explains in a large proportion the annual growth rates for both groups. Moreover, the negative sign of the $\beta$ coefficient confirms the neoclassical growth model assumptions, as the poorer Member increased faster than the developed ones. Based in the equation 2, we have computed the convergence speed for European Union (28), finding evidence in favor of the "2\% rule". According to our calculations, the convergence speed between 1995 and 2019 was $2 \%$ in the European Union, which is in line with the previous studies (Barro and Sala-i-Martin, 1992; Stanišić, 2012; Dobrinsky, 2013; Rapacki and Próchniak, 2019). As far as the New Member States are 
concerned, the convergence speed, as reflected by the $\beta$ coefficient was 3\% per year. Similarly, Matkowski and Próchniak (2007), Rapacki and Próchniak (2009) and Stoica et al. (2019) identified higher speed of convergence in the Central and Eastern European group than the Community's average, reaching on average 3\%. However, we rejected the absolute convergence for the Old Member States group, as the value of coefficients is not statistically significant. Moreover, the value of R-squared was too low to confirm a relationship between the initial level of income and the subsequent growth rates. Similarly, Stanišić (2012) found evidence in favor or absolute convergence at aggregate level, but rejected the hypothesis for the subgroup analysis.

In order to study conditional convergence, we have applied panel regressions based on equation 3 for European Union (28) and the two subgroups of country. The negative sign of $\alpha$ (log of GDP per capita) illustrates the inverse relationship between the initial level of income and the subsequent growth rates. Moreover, the value of coefficient is higher in the conditional framework compared to the absolute one, which confirm the importance of economic and social factors. The results of the panel regressions illustrate the positive influence of the investment in fixed assets, as reflected by the coefficient of general gross fixed capital formation, of the public deficit and trade openness. In contrast, the negative sign of the general government final consumption expenditure emphasize the need to avoid excessive public spending. The value of R-squared suggests that the included variables explain in a proportion of almost 50\% the variation of the GDP per capita. The results are presented in table 4:

Table 4 illustrates the results of the panel regressions employed based on equation 4, which includes both economic and social variables. First of all, the $\alpha_{1}$ coefficient is also negative and statistically significant (pvalue $<1 \%$ ) both at aggregate and subgroup level, confirming the neoclassical growth model assumptions. However, the coefficient is significant lower in the Old Member States group compared to the New Members cluster. The model suggests that factors such as the investment in fixed assets, the openness to trade, the real labor productivity and the labor force participation have a positive influence both at aggregate and subgroup level. The value of R-squared illustrates that the independent variables explain in a large proportion the variation of the GDP per capita between 1995 and 2019, especially in the New Member States group. The two equations confirm the role of the investment in fixed assets, as reflected by the positive and significant value of the gross fixed capital formation and of the trade openness in enhancing economic growth within the European Union. The government deficit had a positive influence on convergence, while general government debt and public consumption hampered the economic growth rates. The second equation illustrate that social determinants have also a strong impact on economic growth, factors such as real labor productivity and labor force participation exerting a positive influence on the convergence process. The results of our research are in line with the previous studies that confirmed the benefic influence of investments and trade (Rapacki and Próchniak, 2009) and the negative consequences of an increased level of government consumption (Rapacki and Próchniak, 2019). Dobrinsky and Havlick, (2014) and Stoica et al. (2019) illustrated that the economic growth in the EU was mainly based on over-indebtedness, while Próchniak (2011) identified a negative relationship between excessive debt and convergence. Raileanu Szeles and Marinescu (2010) and Checherita and Rother (2010) concluded that the large levels of government debt might hamper economic growth.

In order to study if $\beta$-convergence was accompanied by a decrease of income gaps between countries, we have calculated the values of $\sigma$-converge for the European Union and two subgroups. At aggregate level, the income disparities decreased during the 25 -year period with $23 \%$. It seems that the economic and financial crisis obstructed the process of convergence, as no significant improvements took place in the following years. The analysis of the evolution that occurred at subgroup level leads us to paradox conclusions. In the New Member States group, the income gaps decreased with almost $60 \%$, which suggest that the composing countries becoming more and more 
SocioEconomic Challenges, Volume 4, Issue 4, 2020

ISSN (print) - 2520-6621, ISSN (online) - 2520-6214

homogenous in terms of income. The impact of the economic and financial crisis seemed to be on a short-term, as the divergences slightly increased between 2008 and 2010. In contrast, the income disparities between the Old Members almost doubled between 1995 and 2019. As shown above, the income disparities between New and Old Members have increased, mainly starting with 2005. Consequently, we reject the $\sigma$-convergence hypothesis for the Old Member States group.

\section{Conclusion}

The aim of this paper was to study income convergence in the European Union between 1995 and 2019 and to conduct a comparative analysis between the performances of the Old and New Member States. In this respect, we have tried to respond to the question if income convergence is an achievable goal in an enlarged European Union, by examining absolute and conditional $\beta$ - and $\sigma$-convergence. By applying cross-sectional regressions, we have identified an aggregate convergence speed reaching $2 \%$ under the absolute framework. Consequently, we have found evidences in favor of the neoclassical growth model assumptions, as the initially poorer countries from Central and Eastern Europe experienced higher GDP growth rates between 1995 and 2019. However, the subgroup analysis led us to different results. While in the New Members group, the catching-up speed ranged reached $2.7 \%$, no robust evidence in favor of absolute convergence was identified in the Old Member States. In the second part of our paper, we have examined conditional convergence, by including in the regression equation variables aiming the level of investment, the soundness of the public finance, the labor market performances and the demographic trends. Our study confirms the positive influence in the growth process of the gross fixed capital formation, government deficit, trade openness, real labor productivity and labor force participation. In contrast, general government final consumption expenditure, debt, population growth and unemployment had a negative influence of the income per capita growth rates. Consequently, our study emphasizes the need for the European decision makers to rethink the growth model based on over-indebtedness and excessive public spending. The vulnerabilities of this model were brought to the forefront by the economic and financial crisis and its negative consequences are still persistent, mainly among the Southern European Members that find increasingly difficult to maintain economic growth. In contrast, the European Union should focus on promoting trade liberalization, also adopting measures that encourage public and private investments. Moreover, the results of our study suggest the key-role of the labor productivity and labor force participation. Real labor productivity had a positive and statistically significant influence both at aggregate and subgroup level, being one of the main key-drivers of economic growth between 1995 and 2019. One of the vulnerability of the study derives from the limited number of explanatory variables included in the study. Taking into consideration the complexity of the convergence process, our study shows just a small part of the entire picture. Consequently, we propose to expand the present research by incorporating other determinants that might explain the convergence process in the European Union.

Funding: self-funded.

Author Contribution: conceptualization, Ana-Maria Holobiuc; data curation, Ana-Maria Holobiuc; formal analysis, Ana-Maria Holobiuc; funding acquisition, Ana-Maria Holobiuc; investigation, Ana-Maria Holobiuc; methodology, Ana-Maria Holobiuc; project administration, Ana-Maria Holobiuc; resources, Ana-Maria Holobiuc; software, Ana-Maria Holobiuc; supervision, Ana-Maria Holobiuc; validation, Ana-Maria Holobiuc; visualization, Ana-Maria Holobiuc; writing - original draft, Ana-Maria Holobiuc; writing - review \& editing, Ana-Maria Holobiuc.

\section{References}

1. Barro, R. J. and Sala-i-Martin, X. (1992). Convergence. Journal of Political Economy, 100(2), 223-251. https://doi.org/10.1086/261816. 
2. Checherita-Westphal, C. D., Rother, P. (2010). The Impact of High and Growing Government Debt on Economic Growth: An Empirical Investigation for the Euro Area. ECB Working Paper No. 1237. European Central Bank. Available from: https://www.ecb.europa.eu/pub/pdf/scpwps/ecbwp1450.pdf.

3. Dauderstädt, M. (2014). Convergence in Crisis: European Integration in Jeopardy. International Policy Analysis. Friedrich-Ebert-Stiftung.http://gesd.free.fr/dauderstadt14.pdf.

4. Diaz del Hoyo, J. L., Dorrucci, E., Heinz, F. F., Muzikarova, S. (2017). Real Convergence in the Euro Area: A Long-Term Perspective. ECB Occasional Paper, 203. http://doi.org/10.2866/121513

5. Dobrinsky, R. and Havlik, P. (2014). Economic Convergence and Structural Change: the Role of Transition and EU Accession. Research Report No. 395. The Vienna Institute for International Economic Studies. https://wiiw.ac.at/economic-convergence-and-structural-change-the-role-of-transition-and-eu-accession-p3357.html.

6. Dobrinsky, R. (2013). What is Happening to Growth in Europe? Research Report No. 385. The Vienna Institute for International Economic Studies. Available from: https://wiiw.ac.at/what-is-happening-togrowth-in-europe-p-2894.html.

7. Duro, E. (2012). Speed of convergence. CEE and Western Balkans countries. International Journal of Scientific and Engineering Research, 3(4). http://citeseerx.ist.psu.edu/viewdoc/download?doi=10.1.1.302.5056andrep=replandtype=pdf.

8. Eurostat (2020). Database. https://ec.europa.eu/eurostat/data/database.

9. Forgó, B. and Jevčák, A. (2015). Economic Convergence of Central and Eastern European EU Member States over the Last Decade (2004-2014). European Economy Discussion Papers. European Commission.http://dx.doi.org/10.2765/89677

10. Gros, D. (2018). Convergence in the European Union: Inside and outside the euro. Centre for European Policy Studies.https://www.ceps.eu/ceps-publications/convergence-european-union-inside-and-outside-euro/.

11. Holobiuc, A.M and Mihai, B. (2018). Real Convergence in the European Union: Myth or Reality? OEconomica, 3/4, 67-80. http://www.oeconomica.org.ro/abstract/525/Real-Convergence-in-the-EuropeanUnion-Myth-or-Reality.html.

12. Kutan, A. M. and Yigit, T. M. (2005). Real and Nominal Stochastic Convergence: Members Ready to Join the Euro-zone? Journal of Comparative Economics. 33(2), 387-400. https://doi.org/10.1016/j.jce.2005.03.001.

13. Mankiw, G., N., Romer D., Weil, D. N. (1992). A Contribution to the Empirics of Economic Growth. The Quarterly Journal of Economics, 107(2), 407-437. https://doi.org/10.3386/w3541.

14. Matkowski, Z. and Próchniak, M. (2007). Economic Convergence between the CEE-8 and the European Union. Eastern European Economics, 45(1). 59-76. https://doi.org/10.2753/EEE0012-8775450103.

15. Matkowski, Z., Próchniak, M., Rapacki, R. (2016). Real Income Convergence between Central Eastern and Western Europe: Past, Present, and Prospects. 33rd Centre for International Research on Economic Tendency Surveys Conference on Economic Tendency Surveys and Economic Policy (September 14 - September 17, 2016). Available from: https://www.econstor.eu/handle/10419/146992.

16. Nenovsky, N. and Tochkov, K. (2013). The Distribution Dynamics of Income in Central and Eastern Europe relative to the EU: A Nonparametric Analysis. William Davidson Institute Working Paper, 1063. https://dx.doi.org/10.2139/ssrn.2370625.

17. Próchniak, M. (2011). Determinants of economic growth in Central and Eastern Europe: the global crisis perspective. Post-Communist Economies, 23(4), 449-468. DOI: 10.1080/14631377.2011.622566.

18. Raileanu Szeles, M., Marinescu, N., (2010). Real convergence in the CEECs, Euro Area accession and the Role of Romania. European. Journal of Comparative Economics, 7(1), 181-202. https://ideas.repec.org/a/liu/liucej/v7y2010i1p181-202.html.

19. Ramsey, F. P. (1928). A Mathematical Theory of Saving. The Economic Journal, 38 (152), 543-559. https://doi.org/10.1111/ecoj.12229.

20. Rapacki, R. and Próchniak, M. (2009). Real Beta and Sigma Convergence in 27 Transition Countries, 19902005. Post-Communist Economies, 21(3), 307-326. http://doi.org/10.1080/14631370903090616. 
21. Rapacki, R. and Próchniak, M. (2019). EU membership and economic growth: empirical evidence for the CEE countries. European Journal of Comparative Economics, 16(1), 3-40. http://ejce.liuc.it/18242979201901/182429792019160101.pdf.

22. Reza, R. and Zahra K. T. (2008). Evaluation of the Income Convergence Hypothesis in Ten New Members of the European Union. A Panel Unit Root Approach. Panoeconomicus, 55(2), 157-166. http://doi.org/10.2298/PAN0802157R.

23. Solow, R. M. (1956). A Contribution to the Theory of Economic Growth. The Quarterly Journal of Economics, 70(1), 65-94. http://doi.org/10.2307/1884513.

24. Stanišić, N. (2012). The effects of the economic crisis on income convergence in the European Union. Acta Oeconomica, 62(2), 161-182. http://doi.org/10.1556/AOecon.62.2012.2.2.

25. Stoica, O., Roman, A., Diaconaşu, D. E. (2019). Real Convergence and European Integration with Focus on the New Member States. Scientific Annals of Economics and Business, 66(SI2), 215-228. http://dx.doi.org/10.2478/saeb-2019-0035.

26. Vojinović, B., Acharya, S.,Próchniak, M. (2009). Convergence Analysis Among the Ten European Transition Economies. Hitotsubashi Journal of Economics, 50(2), 17-35. http://doi.org/10.15057/18049.

27. World Bank (2020). Data. Available from: https://data.worldbank.org/.

Table 1. Variables, definitions and sources

\begin{tabular}{|l|c|c|}
\hline \multicolumn{1}{|c|}{ Variable } & Definition & Source \\
\hline GDP per capita & $\begin{array}{c}\text { GDP per capita at market prices } \\
\text { (PPS per capita) }\end{array}$ & Eurostat \\
\hline GFCF & Gross fixed capital formation (\% GDP) & World Bank \\
\hline GFCE & $\begin{array}{c}\text { General government final consumption } \\
\text { expenditure (\% of GDP) }\end{array}$ & Eurostat \\
\hline Debt & $\begin{array}{c}\text { General government gross debt } \\
\text { (\% of GDP) }\end{array}$ & Eurostat \\
\hline Deficit & General government deficit (\% of GDP) & World Bank \\
\hline Trade & $\begin{array}{c}\text { Exports and imports of goods and } \\
\text { services (\% GDP) }\end{array}$ & Eurostat \\
\hline RLP & $\begin{array}{c}\text { Real labor productivity per person } \\
\text { (index, 2010=100) }\end{array}$ & World Bank \\
\hline Population & Population growth (\% annual) & World Bank \\
\hline LFP & $\begin{array}{c}\text { Labor force participation rate (\% of } \\
\text { total population ages 15-64) }\end{array}$ & World Bank \\
\hline Unemployment & Unemployment (\% of total labor force) & \\
\hline
\end{tabular}

Source: Author's processing.

$$
\frac{1}{T} \ln \left[\frac{y_{i t}}{y_{i 0}}\right]=a+\alpha_{1} \ln \left(y_{i o}\right)+\varepsilon
$$

$y_{i 0}=$ the initial GDP per capita of economy " $\mathrm{i}$ "

$\mathrm{T}=$ period of time

$\alpha=$ constant

$\varepsilon=$ error term

$$
\beta=-\frac{1}{T} \ln \left(1+\alpha_{1} T\right)
$$

$$
\begin{aligned}
\ln y_{i, t}-\ln y_{i, t-1} & \\
& =a+\alpha_{1} \ln \left(y_{i t-1}\right) \\
& +\alpha_{2}(\text { GFCF })+\alpha_{3}(\text { GFCE })+\alpha_{4}(\text { Debt })+\alpha_{5}(\text { Deficit }) \\
& ++\alpha_{6}(\text { Trade })+\varepsilon
\end{aligned}
$$


$\ln y_{i, t}-\ln y_{i, t-1}$

$$
\begin{aligned}
& =a+\alpha_{1} \ln \left(y_{i t-1}\right) \\
& +\alpha_{2}(\text { GFCF })+\alpha_{3}(\text { GFCE })+\alpha_{4}\left(\text { Debt }+\alpha_{5}(\text { Deficit })\right. \\
& ++\alpha_{6}(\text { Trade })++\alpha_{7}(\text { RLP })+\alpha_{8}(\text { Population })+\alpha_{9}(\text { LFP }) \\
& +\alpha_{10}(\text { Unemplyment })+\varepsilon
\end{aligned}
$$

$\sigma_{t}^{2}=\left(\frac{1}{n}\right) \sum_{i=1}^{N}\left[\left(y_{i t}\right)-\mu_{t}\right]^{2}$

$y_{i t}=$ GDP per capita of economy "i"

$\mu_{t}=$ arithmetic average of $y_{i t}$

\begin{tabular}{|c|c|c|c|c|c|c|}
\hline & & Mean & Median & Max & Min & St. dev. \\
\hline \multirow{3}{*}{ GDP per capita } & EU(28) & 36629.54 & 34230.57 & 115415.4 & 9492.154 & 17713.24 \\
\hline & NMS(13) & 24876.43 & 24927.87 & 43340.20 & 9492.15 & 7823.51 \\
\hline & OMS(15) & 46857.92 & 43526.82 & 115415.4 & 23653.66 & 17574.53 \\
\hline \multirow{3}{*}{ GFCF } & $\mathrm{EU}(28)$ & 22.20 & 21.85 & 43.43 & 9.68 & 4.04 \\
\hline & NMS(13) & 23.22 & 22.56 & 37.28 & 9.68 & 4.44 \\
\hline & OMS(15) & 21.32 & 21.51 & 43.43 & 11.07 & 3.41 \\
\hline \multirow{3}{*}{ GFCE } & EU(28) & 19.67 & 19.37 & 27.93 & 11.67 & 2.89 \\
\hline & NMS(13) & 18.77 & 18.77 & 25.88 & 11.67 & 2.29 \\
\hline & OMS(15) & 20.45 & 19.85 & 27.93 & 11.90 & 3.12 \\
\hline \multirow{3}{*}{ Debt } & $\mathrm{EU}(28)$ & 56.70 & 52.20 & 181.20 & 3.80 & 33.43 \\
\hline & NMS(13) & 40.58 & 38.70 & 109.20 & 3.80 & 23.11 \\
\hline & OMS(15) & 70.73 & 64.30 & 181.20 & 7.40 & 34.71 \\
\hline \multirow{3}{*}{ Deficit } & EU(28) & -2.50 & -2.40 & 6.90 & -32.10 & 3.45 \\
\hline & NMS(13) & -2.81 & -2.60 & 3.30 & -14.60 & 2.94 \\
\hline & OMS(15) & -2.23 & -2.20 & 6.90 & -32.100 & 3.83 \\
\hline \multirow{3}{*}{ Trade } & $\mathrm{EU}(28)$ & 112.19 & 93.93 & 408.36 & 37.10 & 62.98 \\
\hline & NMS(13) & 124.61 & 118.09 & 326.00 & 43.67 & 52.12 \\
\hline & OMS(15) & 101.39 & 77.78 & 408.36 & 37.10 & 69.38 \\
\hline \multirow{3}{*}{ RLP } & $\mathrm{EU}(28)$ & 94.97 & 98.30 & 146.20 & 43.90 & 14.58 \\
\hline & NMS(13) & 91.91 & 97.50 & 142.60 & 43.90 & 18.97 \\
\hline & OMS(15) & 97.64 & 98.85 & 146.20 & 68.40 & 8.35 \\
\hline \multirow{3}{*}{ Population } & $\mathrm{EU}(28)$ & 0.22 & 0.24 & 3.65 & 3.84 & 0.80 \\
\hline & NMS(13) & -0.13 & -0.13 & 3.65 & -3.84 & 0.88 \\
\hline & OMS(15) & 0.54 & 0.44 & 2.89 & -1.85 & 0.57 \\
\hline \multirow{3}{*}{ LFP } & $\mathrm{EU}(28)$ & 70.22 & 70.59 & 83.31 & 57.01 & 5.45 \\
\hline & NMS(13) & 68.42 & 69.20 & 79.12 & 57.09 & 2.01 \\
\hline & OMS(15) & 71.78 & 72.18 & 83.31 & 57.93 & 5.53 \\
\hline \multirow{3}{*}{ Unemployment } & $\mathrm{EU}(28)$ & 8.80 & 7.74 & 27.46 & 1.80 & 4.37 \\
\hline & NMS(13) & 9.26 & 8.00 & 20.7 & 2.01 & 4.21 \\
\hline & OMS(15) & 8.39 & 7.65 & 27.46 & 1.80 & 4.48 \\
\hline
\end{tabular}

$$
\sigma=\sqrt{\sigma^{2}}, \quad C V=\frac{\sigma}{\mu}
$$

Table 2. Descriptive statistics

Source: Author's computation. 
SocioEconomic Challenges, Volume 4, Issue 4, 2020

ISSN (print) - 2520-6621, ISSN (online) - 2520-6214

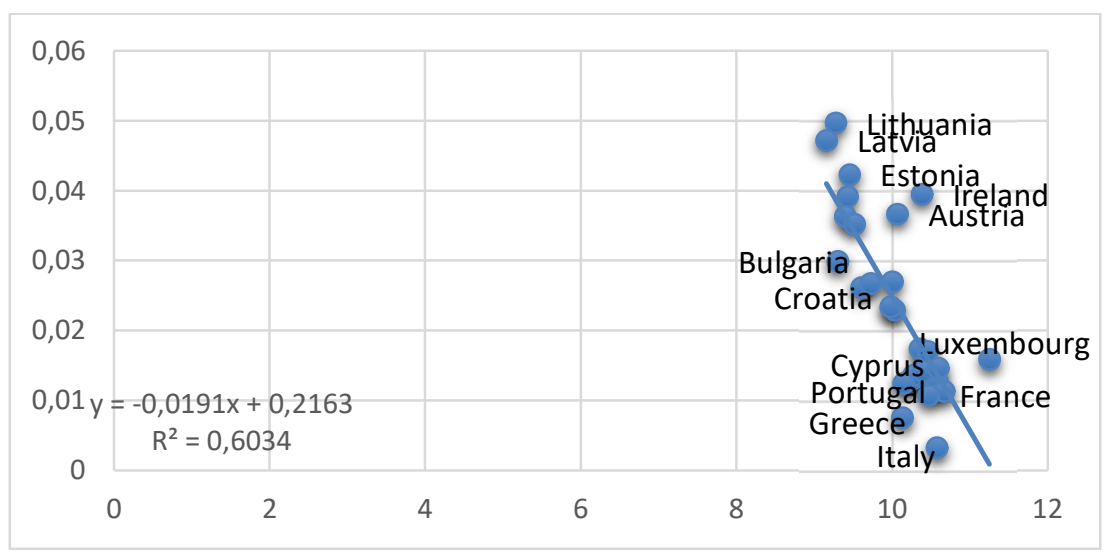

Figure 1. Absolute $\beta$-convergence in the European Union between 1995 and 2019

Source: Author's computation.

Table 3. Absolute convergence results

\begin{tabular}{|l|c|c|c|}
\hline \multicolumn{4}{|c|}{ Dependent Variable: GDP GROWTH RATE BETWEEN 1995-2019 } \\
\hline \multicolumn{2}{|c|}{ Method: Least Squares } & 13 \\
\hline Included observations & 28 & New Member States (13) & Old Member States (15) \\
\hline \multicolumn{1}{|c|}{ Variable } & European Union (28) & $0.2904^{*}$ & 0.1017 \\
$\alpha$ & $0.2218^{*}$ & $(6.7318)$ & -0.0081 \\
\hline LOG(GDP PER CAPITA IN & $(7.0372)$ & $-0.0268^{*}$ & 0.0551 \\
$1995)$ & $-0.0196^{*}$ & $(-5.9893)$ & -0.0175 \\
\hline R-squared & $(-6.2895)$ & 0.7653 & 0.0081 \\
\hline Adjusted R-squared & 0.6034 & 0.7439 & -0.0271 \\
\hline$\beta$ (convergence speed) & 0.5881 & -0.0192 &
\end{tabular}

Note: $*$ - p-value $<1 \%$; $* *$ - p-value $<5 \%$; ${ }^{* * *}$ - p-value $<10 \%$; t-statistics in parentheses.

Source: Author's computation.

Table 4. Conditional convergence results (equation 3)

\begin{tabular}{|l|c|c|c|}
\hline \multicolumn{3}{|c|}{ Dependent Variable: GDP GROWTH RATE BETWEEN 1995-2019 } \\
\hline \multicolumn{2}{|c|}{ Method: Panel Least Squares } \\
\hline Included observations & 667 & 311 & 356 \\
\hline Variable & European Union (28) & New Member States (13) & Old Member States (15) \\
\hline \multirow{2}{*}{$\alpha$} & $0.5852^{*}$ & 0.1320 & $1.1003^{*}$ \\
& $(5.575)$ & $(0.8862)$ & $-0.08753^{*}$ \\
\hline \multirow{2}{*}{ Log(GDP per capita(-1)) } & $-0.0987^{*}$ & $-0.0941^{*}$ & $(-5.5456)$ \\
\hline \multirow{2}{*}{ GFCF } & $(-10.1611)$ & $(-7.5960)$ & $0.0319^{* *}$ \\
& $0.0749^{*}$ & $0.1024^{*}$ & $(2.3495)$ \\
\hline \multirow{2}{*}{ GFCE } & $(6.6698)$ & $(6.7834)$ & $-0.1700^{*}$ \\
& $-0.0619^{*}$ & 0.0082 & $(-5.8880)$ \\
\hline \multirow{2}{*}{ Debt } & $(-3.0689)$ & $(0.3057)$ & -0.0004 \\
& -0.0004 & -0.0010 & $(-0.0694)$ \\
\hline \multirow{2}{*}{ Deficit } & $(-0.0762)$ & $0.1508)$ & 0.0007 \\
& $0.0028^{*}$ & $(7.1103)$ & $(1.0359)$ \\
\hline \multirow{2}{*}{ Trade } & $(5.0853)$ & $0.1095^{*}$ & $\left(3.0600^{*}\right.$ \\
\hline R-squared & $0.0925^{*}$ & $(6.6143)$ & 0.5181 \\
\hline Adjusted R-squared & $(7.5254)$ & 0.4726 & 0.4894 \\
\hline
\end{tabular}

Note: $*$ - p-value $<1 \%$; ** - p-value $<5 \%$; $* * *$ - p-value $<10 \%$; t-statistics in parentheses.

Source: Author's calculations. 
Table 5. Conditional convergence results (equation 4)

\begin{tabular}{|c|c|c|c|}
\hline \multicolumn{4}{|c|}{ Dependent Variable: GDP GROWTH RATE BETWEEN 1995-2019 } \\
\hline \multicolumn{4}{|c|}{ Method: Panel Least Squares } \\
\hline Included observations & 667 & 311 & 356 \\
\hline Variable & European Union (28) & New Member States (13) & Old Member States (15) \\
\hline$\alpha$ & $\begin{array}{l}0.6753^{*} \\
(4.6869)\end{array}$ & $\begin{array}{c}0.9396^{*} \\
(5.0241)\end{array}$ & $\begin{array}{l}0.9826^{*} \\
(5.0361)\end{array}$ \\
\hline Log(GDP per capita(-1)) & $\begin{array}{l}-0.2811^{*} \\
(-9.9597)\end{array}$ & $\begin{array}{c}-0.5090^{*} \\
(-18.2658)\end{array}$ & $\begin{array}{l}-0.1348^{*} \\
(-5.3115)\end{array}$ \\
\hline GFCF & $\begin{array}{c}0.0739^{*} \\
(7.6684) \\
\end{array}$ & $\begin{array}{c}0.0779^{*} \\
(7.3472) \\
\end{array}$ & $\begin{array}{c}0.0322 * * * \\
(1.881)\end{array}$ \\
\hline GFCE & $\begin{array}{c}-0.0294 * * * \\
(-1.8497)\end{array}$ & $\begin{array}{c}-0.0249 \\
(-1.4139)\end{array}$ & $\begin{array}{l}-0.1318^{*} \\
(-4.4154)\end{array}$ \\
\hline Debt & $\begin{array}{c}-0.0076^{* * *} * \\
(-1.7559)\end{array}$ & $\begin{array}{c}-0.0102 * * \\
(-2.2462)\end{array}$ & $\begin{array}{c}-0.0002 \\
(-0.0393)\end{array}$ \\
\hline Deficit & $\begin{array}{l}0.0028^{*} \\
(6.1131)\end{array}$ & $\begin{array}{l}0.0032 * \\
(5.8326)\end{array}$ & $\begin{array}{c}0.0014 * * * \\
(1.8401)\end{array}$ \\
\hline Trade & $\begin{array}{l}0.0580^{*} \\
(5.5953)\end{array}$ & $\begin{array}{c}0.0291^{* *} \\
(2.3934)\end{array}$ & $\begin{array}{c}0.0406^{* *} \\
(2.4459)\end{array}$ \\
\hline RLP & $\begin{array}{l}0.2535^{*} \\
(8.1322)\end{array}$ & $\begin{array}{c}0.5043^{*} \\
(15.5606)\end{array}$ & $\begin{array}{l}0.1176^{*} \\
(3.4677)\end{array}$ \\
\hline Population & $\begin{array}{c}-0.0043 * * * \\
(-1.6950)\end{array}$ & $\begin{array}{c}-0.0024 \\
(-0.7836)\end{array}$ & $\begin{array}{c}-0.0038 \\
(-0.9868) \\
\end{array}$ \\
\hline LFP & $\begin{array}{l}0.1785^{*} \\
(4.5727) \\
\end{array}$ & $\begin{array}{c}0.4056^{*} \\
(8.9364)\end{array}$ & $\begin{array}{c}0.0156 \\
(0.2944) \\
\end{array}$ \\
\hline Unemployment & $\begin{array}{c}-0.0056 \\
(-1.4229)\end{array}$ & $\begin{array}{l}-0.0211^{*} \\
(-4.3690)\end{array}$ & $\begin{array}{c}-0.0034 \\
(-0.6161)\end{array}$ \\
\hline R-squared & 0.5999 & 0.7457 & 0.5554 \\
\hline Adjusted R-squared & 0.5764 & 0.7262 & 0.5232 \\
\hline
\end{tabular}

Note: * p-value $<1 \%$; ** - p-value $<5 \%$; *** - p-value $<10 \%$; t-statistics in parentheses.

Source: Author's calculations.

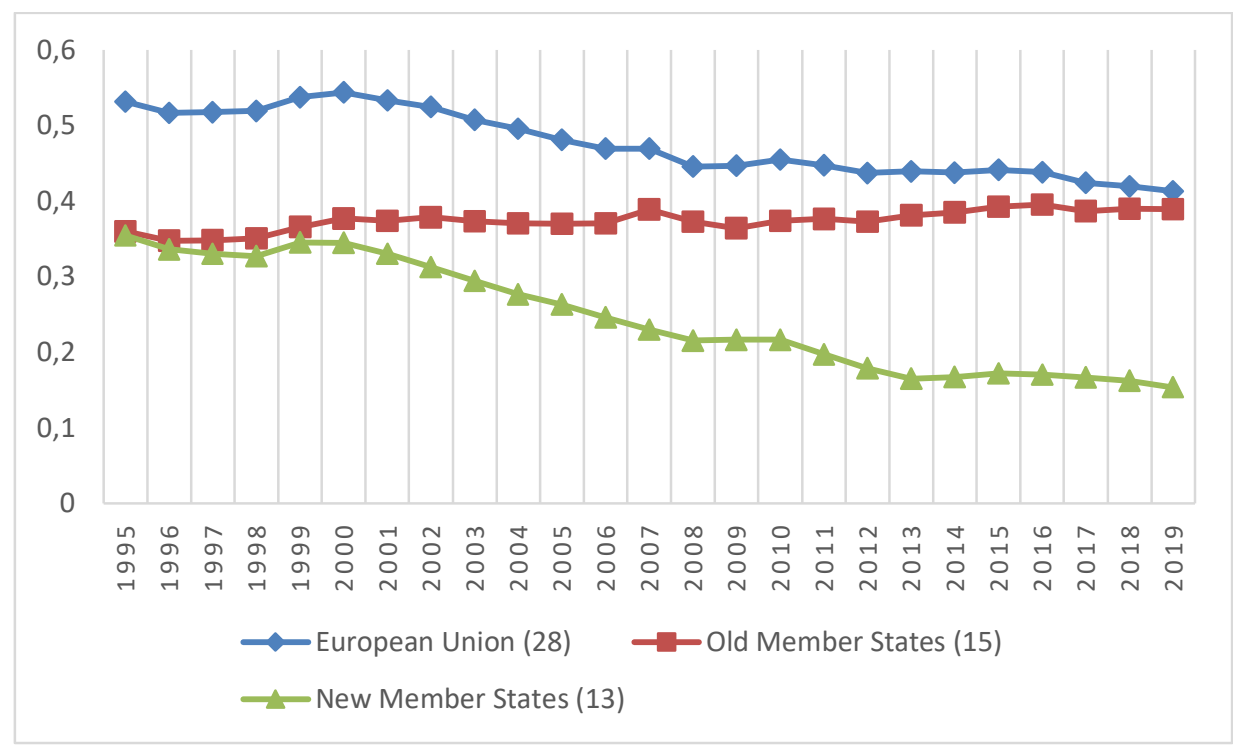

Figure 2. $\sigma$-convergence between 1995 and 2019

Source: Author's computation. 